\title{
Synthesis and Evaluation of Antimicrobial Activity of Nitrones from Derivatives of Aryl-Substituted Dihydroisoquinoline
}

\author{
Mouna Bouzid, ${ }^{1}$ Raed Abdennabi, ${ }^{2}$ Mohamed Damak, ${ }^{1}$ and Majed Kammoun ${ }^{1,3}$ \\ ${ }^{1}$ Laboratory of Chemistry of Natural Products, Faculty of Science, Sfax University, BP 1171, 3000 Sfax, Tunisia \\ ${ }^{2}$ Laboratory of Plant Biotechnology Applied to Crop Improvement, Faculty of Science, Sfax University, BP 1171, 3000 Sfax, Tunisia \\ ${ }^{3}$ Higher Institute of Biotechnology, Sfax University, BP 1172, 3000 Sfax, Tunisia
}

Correspondence should be addressed to Majed Kammoun; majed_kammoun@yahoo.fr

Received 16 February 2015; Revised 25 May 2015; Accepted 25 May 2015

Academic Editor: Andrea Penoni

Copyright (C) 2015 Mouna Bouzid et al. This is an open access article distributed under the Creative Commons Attribution License, which permits unrestricted use, distribution, and reproduction in any medium, provided the original work is properly cited.

\begin{abstract}
This paper describes the synthesis of a series of dihydroisoquinoline nitrones by isomerization of the corresponding oxaziridines. Nitrones $4 \mathbf{a}-\mathbf{c}$ were obtained in excellent yields and high purity by a simple and effective method from the isomerization of oxaziridines. The synthesized compounds were also evaluated for their antibacterial activity against Gram-positive and Gramnegative bacteria and fungus.
\end{abstract}

\section{Introduction}

Nitrones were first used to trap free radicals in chemical systems and then subsequently in biochemical systems. More recently, several nitrones, including alpha-phenyl-tertbutylnitrone (PBN), have been shown to have potent biological activity in many experimental animal models. Many diseases of aging, including stroke, cancer development, Parkinson disease, and Alzheimer disease, are known to have enhanced levels of free radicals and oxidative stress [1].

Nitrones are easily prepared by several methods welldocumented in the primary literature. The most used includes condensation reactions between carbonyl compounds [2, 3] and oxidation of amines, imines, or hydroxylamines $[4,5]$. But the most effective method remains isomerization of oxaziridines [6,7] which are interesting heterocyclic compounds containing oxygen, nitrogen, and carbon atoms in a three-member ring. Since their discovery by Emmons in 1956 [8], oxaziridines have gained increasing attention [9]. In particular, the oxaziridine is of interest because of an inherently weak N-O bond due to the strained ring that makes the molecule unusually highly reactive. These heterocycles have been shown to be promising reagents with potent antitumour [10, 11], antimalarial [12], and antifungal activities [13], and as effective analogues for penicillin [14].
They are also widely used as reagents and intermediates in the preparation of biologically active molecules $[9,15,16]$.

In this paper, we report the synthesis of a series of nitrones by isomerization of the corresponding oxaziridines and their antimicrobial activity.

\section{Experimental}

Solvents were purified by standard methods. Melting points (mp) were determined under microscope with a Leitz Wetzlair device and are uncorrected. LC-MS experiments were carried out with an Agilent 1100 LC system consisting of degasser, binary pump, auto sampler, and column heater. The column outlet was coupled to an Agilent MSD ion Trap XCT mass spectrometer equipped with an ESI ion source. High resolutions (HR) were obtained on a GC-HRMS Micromass Autospec (IE). IR spectra were obtained in $\mathrm{KBr}$ disks on a UR-20 instrument. NMR spectra were recorded on an AC 300 Bruker spectrometer at $300 \mathrm{MHz}$ for ${ }^{1} \mathrm{H}$ and $75 \mathrm{MHz}$ for ${ }^{13} \mathrm{C}$. Chemical shifts $(\delta)$ are given in ppm relative to T.M.S (tetramethylsilane). All reactions were monitored by TLC using commercial silica gel plates and visualization was accomplished by UV light or stained with Dragendorff reagent. 
2.1. Preparation of Imine $2 \boldsymbol{a}$ [17]. To a cooled $\left(0^{\circ} \mathrm{C}\right)$ solution of sulfuric acid $\mathrm{H}_{2} \mathrm{SO}_{4}$ (95\%) was added dropwise $1.1 \mathrm{~mL}$ of $\mathrm{CH}_{3} \mathrm{CN}$ in $20 \mathrm{~mL}$ of hexane under magnetic stirring. Then, tertiary alcohol 1 (commercial product) $15.7 \mathrm{~g}$ with $10.43 \mathrm{mmol}$ in $15 \mathrm{~mL}$ of hexane was added to the solution. After returning to the room temperature, the resulting mixture was stirred at $68^{\circ} \mathrm{C}$ for $2.5 \mathrm{~h}$. Then, the solution is cooled at the room temperature and poured on ice-cold water under magnetic stirring. The solution is alkalized with ammonia. The organic layer is extracted with dichloromethane, washed with a solution saturated in sodium chloride, dried over sodium sulfate, and filtered. The solvent is removed in vacuo.

Yield $80 \% .{ }^{1} \mathrm{H} \mathrm{NMR}\left(\mathrm{CDCl}_{3}, 300 \mathrm{MHz}\right): \delta 1.21(\mathrm{~s}, 6 \mathrm{H}$, $2 \mathrm{CH}_{3}$ ), 2.40 (s, $\left.3 \mathrm{H}, \mathrm{CH}_{3}\right), 2.70\left(\mathrm{~s}, 2 \mathrm{H}, \mathrm{CH}_{2}\right), 7.14(\mathrm{~m}, 1 \mathrm{H})$, $7.29(\mathrm{~m}, 1 \mathrm{H}), 7.35(\mathrm{~m}, 1 \mathrm{H}), 7.49(\mathrm{~m}, 1 \mathrm{H}) .{ }^{13} \mathrm{C} \mathrm{NMR}\left(\mathrm{CDCl}_{3}\right.$, $75 \mathrm{MHz}): \delta$ 23.16, 27.91, 38.91, 53.76, 125.46, 126.86, 127.84, $128.34,130.93,136.37,161.93$. IR (KBr): $v=1574 \mathrm{~cm}^{-1}(\mathrm{Ar})$, $1627 \mathrm{~cm}^{-1}(\mathrm{C}=\mathrm{N}), 2966 \mathrm{~cm}^{-1}\left(\mathrm{CH}_{3}\right)$. GC-MS (EI): $\mathrm{m} / z 173$ $[\mathrm{M}+1]^{+}, 158(100), 145(20), 130(34), 115$ (60), 103 (4), 91 (20), 77 (8), 63 (10), $51(8)$.

2.2. Preparation of Imine $2 \boldsymbol{b}$. To a cooled $\left(0^{\circ} \mathrm{C}\right)$ solution $(10 \mathrm{~mL})$ of sulfuric acid, $\mathrm{H}_{2} \mathrm{SO}_{4}(95 \%)$ was added dropwise and under magnetic stirring, 1 eq of $p$-nitrobenzonitrile in $10 \mathrm{~mL}$ of cyclohexane. Then, $0.5 \mathrm{~g}$ of tertiary alcohol $\mathbf{1}$ (commercial product) in $10 \mathrm{~mL}$ of cyclohexane was added to the solution.

After returning to room temperature, the resulting mixture was stirred under reflux for 2.30 hours. Then, the solution is cooled at the room temperature and versed on icecold water $(50 \mathrm{~mL})$ under magnetic stirring. The solution is alkalized with ammonia. The organic layer was extracted with dichloromethane $(100 \mathrm{~mL})$, washed with a saturated aqueous $\mathrm{NaCl}$ solution, dried over sodium sulfate, and filtered. The solvent was removed in vacuo.

mp $116^{\circ} \mathrm{C}$; Yield 83\%. ${ }^{1} \mathrm{H}$ NMR (300 MHz, $\left.\mathrm{CDCl}_{3}\right): \delta 1.34$ $\left(\mathrm{s}, 6 \mathrm{H}, 2 \mathrm{CH}_{3}\right) ; 2.87\left(\mathrm{~s}, 2 \mathrm{H}, \mathrm{CH}_{2}\right), 7.11\left(\mathrm{~d}, 1 \mathrm{H}, \mathrm{Ar}-\mathrm{H}, J^{3}=\right.$ $5 \mathrm{~Hz}), 7.3(\mathrm{~m}, 2 \mathrm{H}, \mathrm{Ar}-\mathrm{H}), 7.50(\mathrm{~m}, 1 \mathrm{H}, \mathrm{Ar}-\mathrm{H}), 7.78(\mathrm{~d}, 2 \mathrm{H}$, Ar-H, $\left.J^{3}=5 \mathrm{~Hz}\right), 8.32\left(\mathrm{~d}, 2 \mathrm{H}, \mathrm{Ar}-\mathrm{H}, J^{3}=5 \mathrm{~Hz}\right) .{ }^{13} \mathrm{C} \mathrm{NMR}$ $\left(75 \mathrm{MHz}, \mathrm{CDCl}_{3}\right): \delta 27.43,38.73,55.26,123.50,126.85,127.42$, $128.67,129.94,131.58,131.63,137.51,144.93,148.33,163.25$. IR $(\mathrm{KBr}): v=2962 \mathrm{~cm}^{-1}\left(\mathrm{CH}_{3}\right), 2868 \mathrm{~cm}^{-1}\left(\mathrm{CH}_{2}\right), 1518-$ $1345 \mathrm{~cm}^{-1}\left(\mathrm{NO}_{2}\right)$. LC-MS: $m / z 280[\mathrm{M}+1]^{+}$. MS (HR): found mass: 280.1213 mass calculated for $\mathrm{C}_{17} \mathrm{H}_{16} \mathrm{~N}_{2} \mathrm{O}_{2}$ : 280.1212.

2.3. Preparation of Imine $2 \boldsymbol{c}$. The cold imine $\mathbf{2 a}(500 \mathrm{mg}$, $2.80 \mathrm{mmol}$ ) is added dropwise to $2.5 \mathrm{~mL}$ of concentrated sulfuric acid. A solution of $380 \mathrm{mg}$ potassium nitrate in $1.4 \mathrm{~mL}$ of sulfuric acid is added dropwise by maintaining the temperature at less than $0^{\circ} \mathrm{C}$. The reaction medium was stirred at room temperature for $2 \mathrm{~h}$ and then at $60^{\circ} \mathrm{C}$ for $4 \mathrm{~h}$. After returning to room temperature, the reaction medium is poured on ice-cold water and alkalized with ammonia. The organic phase is extracted with the dichloromethane, washed with a solution saturated in sodium chloride, dried on sodium sulfate, and filtered. The solvent was removed in vacuo.

mp: $68^{\circ} \mathrm{C}$; yield $92 \% .{ }^{1} \mathrm{H} \mathrm{NMR}\left(\mathrm{CDCl}_{3}, 300 \mathrm{MHz}\right): \delta 1.20$ (s, 6H, 2CH $\left.\mathrm{CH}_{3}\right), 2.45$ (s, 3H, $\left.\mathrm{CH}_{3}\right), 2.79\left(\mathrm{~s}, 2 \mathrm{H}, \mathrm{CH}_{2}\right), 7.32$ (d, $\left.1 \mathrm{H}, J^{3}=8.1 \mathrm{~Hz}\right), 8.20\left(\mathrm{dd}, 1 \mathrm{H}, J^{3}=8.1 J^{4}=2.1 \mathrm{~Hz}\right), 8.31(\mathrm{~d}, 1 \mathrm{H}$, $\left.J^{4}=2.1 \mathrm{~Hz}\right) .{ }^{13} \mathrm{C} \mathrm{NMR}\left(\mathrm{CDCl}_{3}, 75 \mathrm{MHz}\right): \delta 22.86,27.76,38.91$, $54.27,120.58,125.96,128.84,129.34,143.86,147.16,160.87$. IR (KBr): $v=1335 \mathrm{~cm}^{-1}\left(\mathrm{NO}_{2}\right), 1517 \mathrm{~cm}^{-1}(\mathrm{Ar}), 1626 \mathrm{~cm}^{-1}$ $(\mathrm{C}=\mathrm{N}), 2974 \mathrm{~cm}^{-1}\left(\mathrm{CH}_{3}\right)$. GC-MS (EI): $\mathrm{m} / z 218[\mathrm{M}+1]^{+}, 203$ (67), 190 (32), 176 (18), 157 (52), 144 (8), 130 (22), 115 (57), 102 (9), 89 (15), 76 (11), 63 (9). MS (HR) found mass: 218.1073; mass calculated for $\mathrm{C}_{12} \mathrm{H}_{14} \mathrm{~N}_{2} \mathrm{O}_{2}: 218.1052$.

2.4. Preparation of Oxaziridine 3a. By portions, a slight excess of $m$-chloroperbenzoic acid ( $314 \mathrm{mg}, 1.82 \mathrm{mmol}$ ) was added to a solution of imine $2 \mathrm{a}(300 \mathrm{mg}, 1.73 \mathrm{mmol})$ in methanol $(9 \mathrm{~mL})$ under magnetic stirring and at $0^{\circ} \mathrm{C}$. The reaction was followed by TLC (dichloromethane: methanol $98: 2$ ). The solvent was evaporated, and the residue obtained was taken up in dichloromethane. The solution was washed with a solution of sodium bicarbonate and then with a solution saturated with sodium chloride. The organic phase was dried on sodium sulfate, filtered, and concentrated.

Yield 80\%. ${ }^{1} \mathrm{H}$ NMR $\left(\mathrm{CDCl}_{3}, 300 \mathrm{MHz}\right): \delta 0.91(\mathrm{~s}, 3 \mathrm{H}$, $\left.\mathrm{CH}_{3}\right), 1.47$ (s, 3H, $\left.\mathrm{CH}_{3}\right), 1.89\left(\mathrm{~s}, \mathrm{CH}_{3}\right), 2.35$ (d, $\left.1 \mathrm{H}, \mathrm{CH}_{2}\right), 2.77$ $\left(\mathrm{d}, 1 \mathrm{H}, \mathrm{CH}_{2}\right), 7.08(\mathrm{~m}, 1 \mathrm{H}), 7.28(\mathrm{~m}, 1 \mathrm{H}), 8.20(\mathrm{~m}, 1 \mathrm{H}), 7.62(\mathrm{~m}$, $1 \mathrm{H}) .{ }^{13} \mathrm{C} \mathrm{NMR}\left(\mathrm{CDCl}_{3}, 75 \mathrm{MHz}\right): \delta 21.98,23.08,29.24,37.72$, 56.98, 78.10, 126.95, 128.38, 129.07, 129.54, 131.52, 135.48. IR $(\mathrm{KBr}): \nu=760 \mathrm{~cm}^{-1}(\mathrm{C}-\mathrm{N}), 1525 \mathrm{~cm}^{-1}(\mathrm{Ar}), 2960 \mathrm{~cm}^{-1}\left(\mathrm{CH}_{3}\right)$. MS: $m / z 189[\mathrm{M}+1]^{+}, 174(40), 157$ (100), 142 (30), 130 (54), 115 (44), 103 (14), 91 (24), 77 (20), 56 (14). MS (HR): found mass 189.1134; mass calculated for $\mathrm{C}_{12} \mathrm{H}_{15} \mathrm{NO}$ : 189.1150 .

2.5. Preparation of Oxaziridine $3 \boldsymbol{b}$. To a solution of imine, $\mathbf{2 b}$ in methanol $(9 \mathrm{~mL})$ was added in small portions, with a slight excess of $m$-chloroperbenzoic acid (1 equiv of active oxygen) under magnetic stirring and at room temperature. The reaction was followed by TLC $\left(\mathrm{CH}_{2} \mathrm{Cl}_{2} / \mathrm{MeOH}: 98: 2\right)$. The solvent was evaporated and the residue obtained was taken up in dichloromethane $(50 \mathrm{~mL})$. The solution was washed with a solution of sodium bicarbonate and then with a saturated aqueous $\mathrm{NaCl}$ solution. The organic phase was dried over sodium sulfate, filtered, and concentrated.

mp: $90^{\circ} \mathrm{C}$; Yield 91\%. ${ }^{1} \mathrm{H}$ NMR $\left(300 \mathrm{MHz}, \mathrm{CDCl}_{3}\right): \delta 1.16$ $\left(\mathrm{s}, 3 \mathrm{H}, \mathrm{CH}_{3}\right), 1.57\left(\mathrm{~s}, 3 \mathrm{H}, \mathrm{CH}_{3}\right), 2.60\left(\mathrm{~d}, 1 \mathrm{H}, \mathrm{CH}_{2}, J^{2}=15 \mathrm{~Hz}\right)$, $2.93\left(\mathrm{~d}, 1 \mathrm{H}, \mathrm{CH}_{2}, J^{2}=15 \mathrm{~Hz}\right), 6.93\left(\mathrm{~d}, 1 \mathrm{H}, \mathrm{Ar}-\mathrm{H}, J^{3}=10 \mathrm{~Hz}\right)$, 7.20 (m, 2H, Ar-H), 7.46 (m, 1H, Ar-H), 7.76 (d, 2H, Ar-H, $J^{3}=$ $10 \mathrm{~Hz}), 8.36\left(\mathrm{~d}, 2 \mathrm{H}, \mathrm{Ar}-\mathrm{H}, J^{3}=10 \mathrm{~Hz}\right) .{ }^{13} \mathrm{C} \mathrm{NMR}(75 \mathrm{MHz}$, $\mathrm{CDCl}_{3}$ ): $\delta 22.17,28.64,37.15,57.09,81.07,123.45,126.43,128.40$, 129.03 (2C), 129.97, 130.26, 135.41, 144.16, 147.99. IR (KBr): $\nu=$ $2964 \mathrm{~cm}^{-1}\left(\mathrm{CH}_{3}\right), 2869 \mathrm{~cm}^{-1}\left(\mathrm{CH}_{2}\right), 1603 \mathrm{~cm}^{-1}$ (Ar), $1520-$ $1348 \mathrm{~cm}^{-1}\left(\mathrm{NO}_{2}\right)$. LC-MS: $m / z 296[\mathrm{M}+1]^{+}$, MS (HR): found mass: 296.1166 mass calculated for $\mathrm{C}_{17} \mathrm{H}_{16} \mathrm{~N}_{2} \mathrm{O}_{3}$ : 296.1161.

2.6. Preparation of Oxaziridine 3c. Small portions, a slight excess of $m$-chloroperbenzoic acid ( $415 \mathrm{mg}, 2.40 \mathrm{mmol}$ ), were added to a solution of imine $2 \mathrm{c}(500 \mathrm{mg}, 2.29 \mathrm{mmol})$ in methanol under magnetic stirring at $0^{\circ} \mathrm{C}$. The reaction was followed by TLC (dichloromethane : methanol $95: 5$ ).

The solvent was evaporated, and the residue obtained was taken up in dichloromethane. The solution was washed with a solution of sodium bicarbonate and then with a saturated 
solution of sodium chloride. The organic phase was dried on sodium sulfate, filtered, and concentrated. The resulting yellow solid was purified by crystallization from ether: hexane $(1: 1)$ affording colorless crystals of oxaziridine $\mathbf{3 c}$.

mp: $72^{\circ} \mathrm{C}$; yield $84 \%$. $1 \mathrm{H} \mathrm{NMR}\left(\mathrm{CDCl}_{3}, 300 \mathrm{MHz}\right): \delta 0.91$ (s, $\left.3 \mathrm{H}, \mathrm{CH}_{3}\right), 1.52\left(\mathrm{~s}, 3 \mathrm{H}, \mathrm{CH}_{3}\right), 2.00\left(\mathrm{~s}, \mathrm{CH}_{3}\right), 2.50(\mathrm{~d}, 1 \mathrm{H}$, $\left.\mathrm{CH}_{2}, J^{2}=15.7 \mathrm{~Hz}\right), 2.81\left(\mathrm{~d}, 1 \mathrm{H}, \mathrm{CH}_{2}, J^{2}=15.7 \mathrm{~Hz}\right), 7.28(\mathrm{~d}, 1 \mathrm{H}$, $\left.J^{3}=8.4 \mathrm{~Hz}\right), 8.2\left(\mathrm{dd}, 1 \mathrm{H}, J^{3}=8.4, J^{4}=2.1 \mathrm{~Hz}\right), 8.50(\mathrm{~d}, 1 \mathrm{H}$, $\left.J^{4}=2.1 \mathrm{~Hz}\right) .{ }^{13} \mathrm{C} \mathrm{NMR}\left(\mathrm{CDCl}_{3}, 75 \mathrm{MHz}\right): \delta 21.29,22.61,28.65$, $37.31,56.80,76.99,123.24,124.18,129.68,133.20,142.77,146.83$. IR (KBr): $v=740 \mathrm{~cm}^{-1}(\mathrm{C}-\mathrm{N}), 1350 \mathrm{~cm}^{-1}\left(\mathrm{NO}_{2}\right), 1527 \mathrm{~cm}^{-1}$ (Ar), $2965 \mathrm{~cm}^{-1}\left(\mathrm{CH}_{3}\right)$. MS (EI): $\mathrm{m} / z 234[\mathrm{M}+1]^{+}, 218(234-$ 16). Anal. calc. for $\mathrm{C}_{12} \mathrm{H}_{14} \mathrm{O}_{3} \mathrm{~N}_{2}$ : C, 61.53; $\mathrm{H}, 6.02 ; \mathrm{O}, 20.49$; N, 11.96. Found: C, 61.58; H, 5.85; O, 20.69; N, 11.77.

2.7. Preparation of Nitrone $4 \boldsymbol{a}$. Methanesulfonic acid (76 mg, $0.79 \mathrm{mmol}$ ) was added to a solution of oxaziridine $\mathbf{3 a}$ (50 $\mathrm{mg}, 0.26 \mathrm{mmol})$ in dichloromethane $(5 \mathrm{~mL})$. The solution was stirred at room temperature, diluted with the dichloromethane, and washed with a solution of sodium bicarbonate. The organic phase was dried on sodium sulfate, filtered, and concentrated.

Yield $85 \% .{ }^{1} \mathrm{H}$ NMR $\left(\mathrm{CDCl}_{3}, 300 \mathrm{MHz}\right): \delta 1.43(\mathrm{~s}, 6 \mathrm{H}$, $\left.2 \mathrm{CH}_{3}\right), 2.44\left(\mathrm{~s}, 3 \mathrm{H}, \mathrm{CH}_{3}\right), 3.03\left(\mathrm{~s}, 2 \mathrm{H}, \mathrm{CH}_{2}\right), 7.18(\mathrm{~m}, 1 \mathrm{H})$, $7.26(\mathrm{~m}, 2 \mathrm{H}), 7.31(\mathrm{~m}, 1 \mathrm{H}) .{ }^{13} \mathrm{C}$ NMR $\left(\mathrm{CDCl}_{3}, 75 \mathrm{MHz}\right): \delta$ 25.15, 30.09, 42.16, 53.84, 124.29, 127.68, 128.08, 128.99, 130.80, 134.29, 141.17. IR (KBr): $\nu=1582 \mathrm{~cm}^{-1}(\mathrm{Ar}), 1600 \mathrm{~cm}^{-1}(\mathrm{C}=\mathrm{N})$, $2358 \mathrm{~cm}^{-1}\left(\mathrm{~N}^{+}-\mathrm{O}^{-}\right)$. MS (EI): $m / z 189[\mathrm{M}+1]^{+}, 174(48), 157$ (100), 142 (36), 130 (70), 115 (70), 103 (18), 91 (22), 77 (20), 65 (16), 51 (12). Found mass: 189.1164; mass calculated for $\mathrm{C}_{12} \mathrm{H}_{15} \mathrm{NO}: 189.1150$.

2.8. Preparation of Nitrone $4 \boldsymbol{b}$. Methanesulfonic acid $(160 \mathrm{mg}, 5 \mathrm{eq})$ was added to a solution of oxaziridine $\mathbf{3 b}$ $(100 \mathrm{mg})$ in dichloromethane $(5 \mathrm{~mL})$ and the mixture was stirred at room temperature. A control of the reaction mixture by TLC (dichloromethane) indicated the disappearance of the oxaziridine. The solution was diluted with dichloromethane $(25 \mathrm{~mL})$ and washed with a solution of sodium bicarbonate. The organic phase was dried over sodium sulfate, filtered, and concentrated.

$\mathrm{mp} 156{ }^{\circ} \mathrm{C}$; Yield $75 \% ;{ }^{1} \mathrm{H}$ NMR $\left(300 \mathrm{MHz}, \mathrm{CDCl}_{3}\right): \delta 1.56$ (s, $\left.6 \mathrm{H}, 2 \mathrm{CH}_{3}\right), 3.23\left(\mathrm{~s}, 2 \mathrm{H}, \mathrm{CH}_{2}\right), 6.77\left(\mathrm{~d}, 1 \mathrm{H}, \mathrm{Ar}-\mathrm{H},{ }^{3} \mathrm{~J}=\right.$ $10 \mathrm{~Hz}), 7.30(\mathrm{~m}, 2 \mathrm{H}, \mathrm{Ar}-\mathrm{H}), 7.35(\mathrm{~m}, 1 \mathrm{H}, \mathrm{Ar}-\mathrm{H}), 7.76(\mathrm{~d}, 2 \mathrm{H}$, Ar- $\left.\mathrm{H},{ }^{3} \mathrm{~J}=10 \mathrm{~Hz}\right), 8.36\left(\mathrm{~d}, 2 \mathrm{H}, \mathrm{Ar}-\mathrm{H},{ }^{3} \mathrm{~J}=10 \mathrm{~Hz}\right) .{ }^{13} \mathrm{C}$ NMR $\left(75 \mathrm{MHz}, \mathrm{CDCl}_{3}\right): \delta 24.57,41.64,67.77,123.45,125.71,127.26$, $128.02,129.23,130.22,130.98,131.56,138.76,139.64,147.73$. IR (KBr) $v, \mathrm{~cm}^{-1}: 3026\left(\mathrm{CH}_{3}\right), 2933\left(\mathrm{CH}_{2}\right), 1513-1341\left(\mathrm{NO}_{2}\right)$. LCMS: $m / z 296[\mathrm{M}+1]^{+}$. MS (HR): found mass: 296.1166 mass calculated for $\mathrm{C}_{17} \mathrm{H}_{16} \mathrm{~N}_{2} \mathrm{O}_{3}: 296.1161$.

2.9. Preparation of Nitrone $4 c$. Methanesulfonic acid (123 mg, $1.27 \mathrm{mmol}$ ) was added to a solution of oxaziridine $3 \mathrm{c}$ $(100 \mathrm{mg}, 0.42 \mathrm{mmol})$ in dichloromethane $(5 \mathrm{~mL})$. The solution was stirred at room temperature, diluted with the dichloromethane, and washed with a solution of sodium bicarbonate. The organic phase was dried on sodium sulfate, filtered, and concentrated.
TABLE 1: Yields of nitrones $\mathbf{4 a - c}$.

\begin{tabular}{lccc}
\hline Nitrone & $\mathrm{X}$ & $\mathrm{R}$ & Yield \\
\hline $\mathbf{4 a}$ & $\mathrm{H}$ & $\mathrm{Me}$ & $85 \%$ \\
$\mathbf{4 b}$ & $\mathrm{H}$ & $4-\mathrm{C}_{6} \mathrm{H}_{4}-\mathrm{NO}_{2}$ & $75 \%$ \\
$\mathbf{4}$ & $\mathrm{NO}_{2}$ & $\mathrm{Me}$ & $84 \%$ \\
\hline
\end{tabular}

mp $106-108^{\circ} \mathrm{C}$, yield $84 \% .{ }^{1} \mathrm{H}$ NMR $\left(\mathrm{CDCl}_{3}, 300 \mathrm{MHz}\right)$ : $\delta 1.56\left(\mathrm{~s}, 6 \mathrm{H}, 2 \mathrm{CH}_{3}\right), 2.69\left(\mathrm{~s}, 3 \mathrm{H}, \mathrm{CH}_{3}\right), 3.78\left(\mathrm{~s}, 2 \mathrm{H}, \mathrm{CH}_{2}\right)$, $7.32\left(\mathrm{~d}, 1 \mathrm{H}, J^{3}=8.4 \mathrm{~Hz}\right), 8.25\left(\mathrm{dd}, 1 \mathrm{H}, J^{3}=8.4 \mathrm{~Hz}, J^{4}=\right.$ $2.1 \mathrm{~Hz}), 8.55\left(\mathrm{~d}, 1 \mathrm{H}, J^{4}=2.1 \mathrm{~Hz}\right) .{ }^{13} \mathrm{C} \mathrm{NMR}\left(\mathrm{CDCl}_{3}, 75 \mathrm{MHz}\right)$ : $\delta 25.77,29.73,41.28,88.97,124.07,125.87,133.47,139.63,142.20$, 146.89, 199.94. IR (KBr): $v=1346 \mathrm{~cm}^{-1}\left(\mathrm{NO}_{2}\right), 1515 \mathrm{~cm}^{-1}$ (Ar), $1610 \mathrm{~cm}^{-1}(\mathrm{C}=\mathrm{N}), 2360 \mathrm{~cm}^{-1}\left(\mathrm{~N}^{+}-\mathrm{O}^{-}\right)$. MS (EI): $\mathrm{m} / z$ $234[\mathrm{M}+1]^{+}$. Anal. calc. for $\mathrm{C}_{12} \mathrm{H}_{14} \mathrm{O}_{3} \mathrm{~N}_{2}$ : C, 61.53; $\mathrm{H}, 6.02$; O, 20.49; N, 11.96. Found: C, 61.51; H, 6.16; O, 20.49; N, 11.8.

\section{Results and Discussion}

3.1. Chemistry. In this study, we have developed a simple and efficient synthetic method of dihydroisoquinoline nitrone from the corresponding oxaziridines. The oxaziridines presented in this paper were synthesized starting from the commercial tertiary alcohol $\mathbf{1}$ (Scheme 1).

The imines $\mathbf{2} \mathbf{a}$ or $\mathbf{2} \mathbf{b}$ from step (x) were obtained by acid catalyzed reaction of 2-methyl-1-phenylpropan-2-ol 1 by Ritter-type procedure with acetonitrile or benzonitrile. The nitration of imine 2a under mild conditions leads to imine $2 c$. The peracid oxidation of imines $2 \mathbf{a}-\mathbf{c}$ leads quickly to oxaziridines $3 \mathbf{a}-\mathbf{c}$ in good yields (Scheme 1).

The oxaziridines $\mathbf{3 a}$ and $\mathbf{3} \mathbf{c}$ have been previously reported to be an excellent agent for the transfer of oxygen on organosulfides, if the oxygen transfer is promoted by an acid [18].

Indeed, in the absence of sulfide, oxaziridine, which can be O-protonated, isomerizes into nitrone (Scheme 2).

The isomerization reaction of oxaziridines $\mathbf{3 a}-\mathbf{c}$ (Scheme 3) with 5 equivalents of methanesulfonic acid $\left(\mathrm{CH}_{3} \mathrm{SO}_{3} \mathrm{H}\right)$ leads to nitrone $\mathbf{4 a}-\mathbf{c}$ with goods yields, respectively (Table 1 ).

\subsection{Biology}

3.2.1. Antimicrobial Activities. All the synthesized compounds were screened for their antibacterial activities. For this study, microorganisms employed were B. thuringiensis, $E$. coli, B. subtilis, K. pneumoniae, and E. faecalis. Antimicrobial studies were assessed by minimum inhibition concentration (MIC) method by the serial dilution technique.

The results of antimicrobial testing are reported in (Table 2).

From the antimicrobial activity study, it was found that compounds $4 \mathbf{a}$ exhibited an excellent activity against bacteria B. thuringiensis and E. coli.

3.2.2. Minimal Inhibitory Concentrations (MIC). Table 3 revealed that all compounds showed antimicrobial activities. 


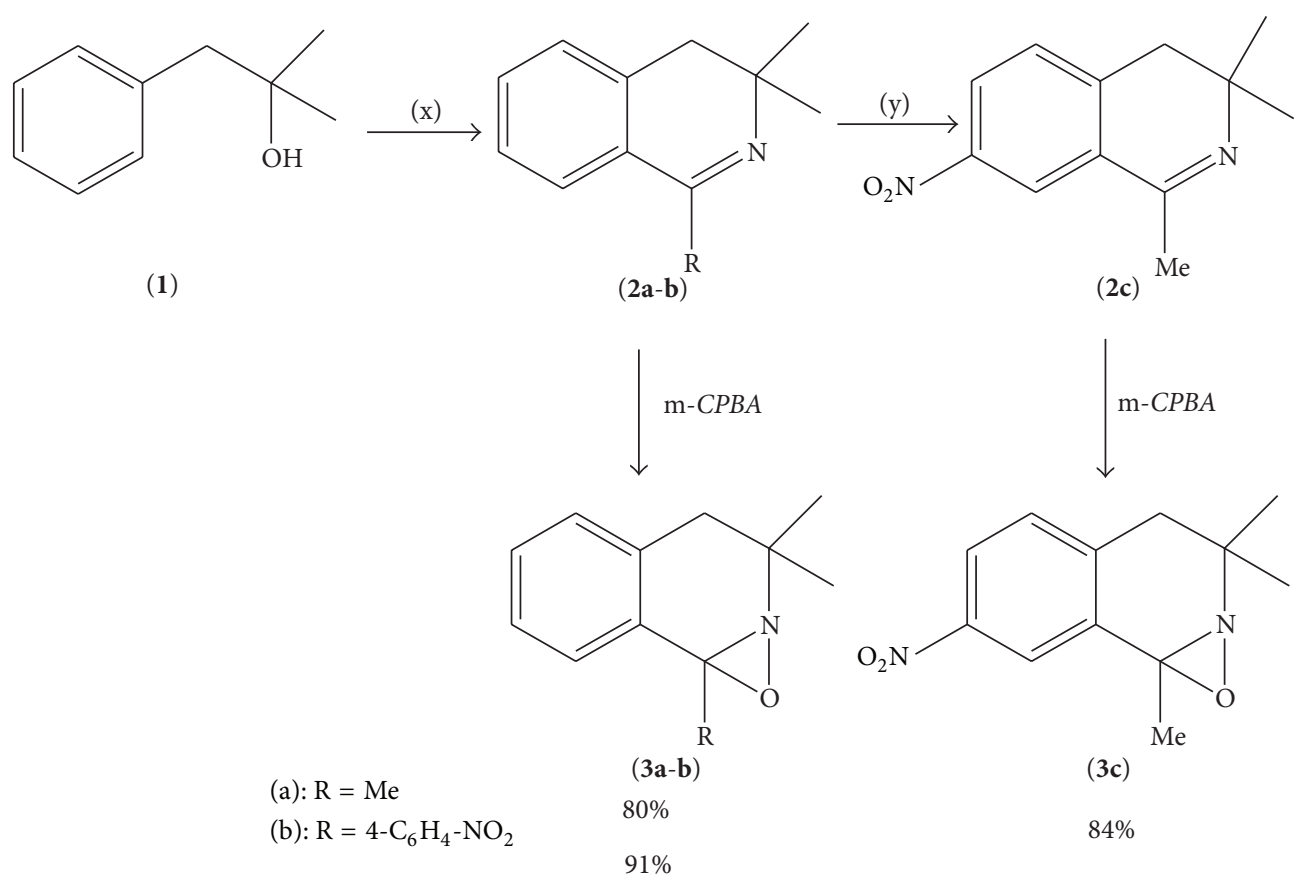

(x): $\mathrm{H}_{2} \mathrm{SO}_{4}, \mathrm{R}-\mathrm{CN}$, hexane $/ 3 \mathrm{~h}$ at $68^{\circ} \mathrm{C}$

(y): $\mathrm{KNO}_{3}, \mathrm{H}_{2} \mathrm{SO}_{4} / 2 \mathrm{~h}$ at $20^{\circ} \mathrm{C}$ than $4 \mathrm{~h}$ at $60^{\circ} \mathrm{C}$

Scheme 1: Reagents and conditions of oxaziridines $\mathbf{3 a}-\mathbf{c}$ synthesis.

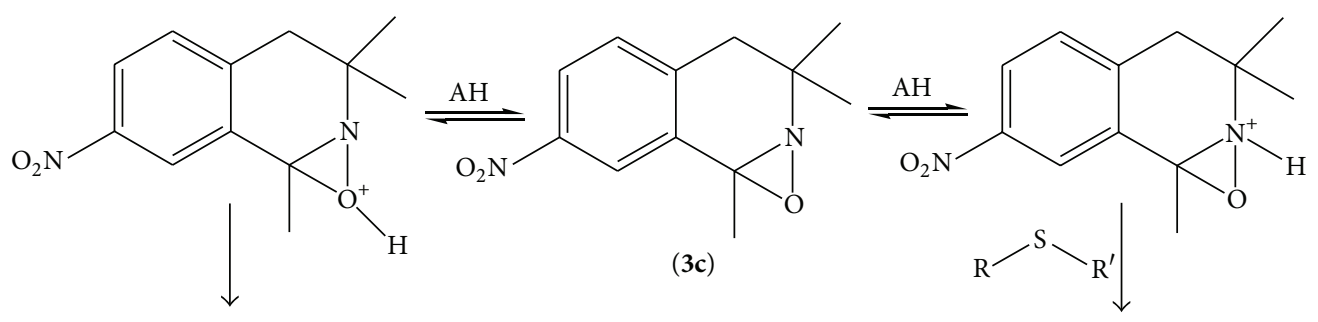<smiles>CC1=[N+](O)C(C)(C)Cc2ccc([N+](=O)[O-])cc21</smiles><smiles>[R][SH]([R])[O-]</smiles>

Scheme 2: Oxaziridine $3 \mathrm{c}$ under the action of acid.<smiles>[X]c1ccc2c(c1)C1([R])ON1C(C)(CC)C2</smiles>

$(3 \mathbf{a}-\mathbf{c})$<smiles>[R]C1=[N+]([O-])C(C)(C)Cc2ccc([X])cc21</smiles>

$(4 a-c)$

$\mathrm{X}=\mathrm{H}, \mathrm{NO}_{2}$

$\mathrm{R}=\mathrm{Me}, 4-\mathrm{C}_{6} \mathrm{H}_{4}-\mathrm{NO}_{2}$

(f): $\mathrm{CH}_{3} \mathrm{SO}_{3} \mathrm{H}, \mathrm{NaHCO}_{3}, \mathrm{CH}_{2} \mathrm{Cl}_{2}$

Scheme 3: Synthesis of nitrones. 
TABLE 2: Antimicrobial activity of synthesized compounds $\mathbf{4 a}-\mathbf{c}^{(\mathrm{a}, \mathrm{b}, \mathrm{c})}$ compared to an antibiotic like penicillin (P).

\begin{tabular}{lccccc}
\hline \multirow{2}{*}{ Compounds } & & \multicolumn{3}{c}{ Inhibition zone diameter $(\mathrm{mm})$} & \\
& B. thuringiensis & E. coli & B. subtilis & K. pneumoniae & - \\
\hline 4a & $15 \pm 0.35$ & $12 \pm 0.14$ & - & - & - \\
$\mathbf{4 b}$ & - & - & $12 \pm 1.06$ & - & - \\
$\mathbf{4 c}$ & - & $12 \pm 0.53$ & - & $10 \pm 0.35$ \\
$\mathbf{P}$ & $\mathrm{R}$ & $14 \pm 0.70$ & $14 \pm 0.25$ & $14 \pm 0.00$ \\
\hline
\end{tabular}

B. thuringiensis: Bacillus thuringiensis; E. coli: Escherichia coli; B. subtilis: Bacillus subtilis; K. pneumoniae: Klebsiella pneumoniae; E. faecalis: Enterococcus faecalis; R: resistant.

${ }^{a}$ Sample concentration: $8 \mathrm{mg} / \mathrm{Ml}$. Sample volume $1000 \mu \mathrm{L} /$ well.

${ }^{\mathrm{b}}$ Results are calculated after subtraction of $\mathrm{MeOH}$ activity.

${ }^{c}$ Not active (inhibition zone $<2 \mathrm{~mm}$ ); weak activity $(2-8 \mathrm{~mm})$; moderate activity $(9-15 \mathrm{~mm})$; strong activity $(>15 \mathrm{~mm})$.

TABLE 3: Antimicrobial activity of the compounds using minimal inhibition concentration (MIC).

\begin{tabular}{lccccc}
\hline \multirow{2}{*}{ Compound } & \multicolumn{4}{c}{ Minimal inhibition concentration (MIC) $\mathrm{mg} \cdot \mathrm{mL}^{-1}$} \\
& B. thuringiensis & E. coli & B. subtilis & K. pneumoniae & E. faecalis \\
\hline 4a & 20 & 40 & - & - \\
4b & - & - & 40 & - \\
4c & - & 40 & - & - \\
\hline
\end{tabular}

The maximum MIC was recorded against E. coli with both compounds $\mathbf{4 a}$ and $\mathbf{4 b}$ and against $B$. subtilis with the latest product $\mathbf{4 c}$. The results presented here are promising, since the activity against Gram-positive bacteria is high, even if it has activity for Gram-negative bacteria. As it is well known, the structure of the form of Gram-negative bacteria has additional layers that make extracellular defense wall. The compounds $\mathbf{4 a}$ and $\mathbf{4 b}$ are active against $E$. coli at a concentration of $40 \mathrm{mg} \cdot \mathrm{mL}^{-1}$ which shows the stiffness of the wall of the compound where the strain weakens the bacterial cell wall with a high concentration. Generally, the change in concentration depends on the resistance of the bacterial strain.

\subsection{Biological Testing}

3.3.1. Antimicrobial Activity. All the newly synthesized compounds were evaluated for their antimicrobial activities against various microorganisms representing Gram-positive bacteria (Bacillus thuringiensis, B. subtilis, and E. faecalis) and Gram-negative bacteria (Escherichia coli, K. pneumoniae), using the minimum inhibition concentration (MIC) method by the serial dilution technique.

The culture medium used is Mueller Hinton, which is the most used medium for susceptibility testing antibacterial agents, with a concentration $38 \mathrm{~g} / \mathrm{L}$.

In a test tube containing $2 \mathrm{~mL}$ of Muller Hinton liquid, colony of each reference strain was seeded. This preculture is subjected during $18 \mathrm{H}$ at $37^{\circ} \mathrm{C} .20 \mu \mathrm{L}$ of preculture was added to $2 \mathrm{~mL}$ of Muller Hinton liquid; the whole is incubated $3-5 \mathrm{~h}$ at $37^{\circ} \mathrm{C}$ to reach exponential phase.

On Muller Hinton solid medium, $30 \mu \mathrm{L}$ of the cell suspension is spread on the box kneaded and after a period of time the wells were created on the box.

$50 \mu \mathrm{L}$ of each product is placed in each well. The box is left 2 to $3 \mathrm{~h}$ at $4^{\circ} \mathrm{C}$ for the proper dissemination of the extract.
After incubation, the dishes are put in the oven according to the temperature corresponding to each strain.

The results of the antimicrobial studies are summarized in Table 2.

3.3.2. Determination of the Minimal Inhibitory Concentration (MIC). The minimum inhibitory concentrations (MIC) of the synthesized nitrones $(\mathbf{4 a}-\mathbf{c})$ were determined for each antimicrobial activity against selected microorganisms by using agar diffusion method.

The results of the antimicrobial studies using MIC are summarized in Table 3.

\section{Conclusion}

A novel series of nitrones was synthesized by a simple method and with good yields. All the compounds were screened for their antibacterial activity by agar diffusion method and serial dilution method. Compound $\mathbf{4 a}$ has showed excellent antimicrobial activity against Gram-positive and Gram-negative bacteria.

\section{Conflict of Interests}

The authors declare that there is no conflict of interests regarding the publication of this paper.

\section{Acknowledgment}

The authors gratefully acknowledge the financial support of the Ministry of Higher Education, Scientific Research and Technology in Tunisia. 


\section{References}

[1] R. A. Floyd, R. D. Kopke, C.-H. Choi, S. B. Foster, S. Doblas, and R. A. Towner, "Nitrones as therapeutics," Free Radical Biology and Medicine, vol. 45, no. 10, pp. 1361-1374, 2008.

[2] S. Franco, F. L. Merchan, P. Merino, and T. Tejero, "An improved synthesis of ketonitrones," Synthetic Communications, vol. 25, no. 15, pp. 2275-2284, 1995.

[3] A. Dondoni, S. Franco, F. Junquera, F. Merchan, P. Merino, and T. Tejero, "Synthesis of N-benzyl nitrones," Synthetic Communications, vol. 24, no. 18, pp. 2537-2550, 1994.

[4] S. I. Murahashi, "Synthetic aspects of metal-catalyzed oxidations of amines and related reactions," Angewandte Chemie International Edition in English, vol. 34, no. 22, pp. 2443-2465, 1995.

[5] S.-I. Murahashi, H. Mitsui, T. Shiota, T. Tsuda, and S. J. Watanabe, "Tungstate-catalyzed oxidation of secondary amines to nitrones. $\alpha$-substitution of secondary amines via nitrones," The Journal of Organic Chemistry, vol. 55, no. 6, pp. 1736-1744, 1990.

[6] G. Hanquet, X. Lusinchi, and P. Milliet, "Acid catalyzed oxygen transfer from an oxaziridine to a thioether," Tetrahedron Letters, vol. 29, no. 23, pp. 2817-2818, 1988.

[7] M. Kammoun, H. B. Salah, and M. Damak, "Synthesis and reactivity study of two new dihydroisoquinoline-derived oxaziridines," Synthetic Communications, vol. 41, no. 10, pp. 15201528, 2011.

[8] W. D. Emmons, "The synthesis of oxaziranes," Journal of the American Chemical Society, vol. 78, no. 23, pp. 6208-6209, 1956.

[9] F. A. Davis and A. C. Sheppard, "Applications of oxaziridines in organic synthesis," Tetrahedron, vol. 45, no. 18, pp. 5703-5742, 1989.

[10] J. Mlochowski, E. Kubicz, K. Kloc, M. Mordarski, W. Peczyńska, and L. Syper, "Synthesis of oxaziridinylquinones and oxaziridinylazines as potential antitumor agents," Liebigs Annalen der Chemie, vol. 1988, no. 5, pp. 455-464, 1988.

[11] S. B. Said, J. Młochowski, and J. Skarżewski, "Synthesis of 2alkyl-3-vinyloxaziridines as potential antitumor agents," Liebigs Annalen der Chemie, vol. 1990, no. 5, pp. 461-464, 1990.

[12] N. Ningsanont, D. S. C. Black, R. Chanphen, and Y. J. Thebtaranonth, "Synthesis of ethyl 5-phenyl-6-oxa-1-azabicyclo[3.1.0] hexane-2-carboxylate derivatives and evaluation of their antimalarial activities," Journal of Medicinal Chemistry, vol. 46, no. 12, pp. 2397-2403, 2003.

[13] L. Peng, C. Chen, C. R. Gonzalez, and V. Balogh-Nair, "Bioorganic studies in AIDS: synthetic antifungals against Pneumocystis carinii based on the multivalency concept," International Journal of Molecular Sciences, vol. 3, no. 11, pp. 1145-1161, 2002.

[14] J. Marchand-Brynaert, Z. Bounkhala-Khrouz, H. Vanlierde, and L. Ghosez, "Oxaziridines and nitrones as potential inhibitors of bacterial D,D-peptidases," Heterocycles, vol. 30, no. 2, pp. 971-982, 1990.

[15] J. Aubé, "Oxiziridine rearrangements in asymmetric synthesis," Chemical Society Reviews, vol. 26, pp. 269-277, 1997.

[16] Y. Kacem, J. Kraiem, E. Kerkeni, A. Bouraoui, and B. Ben Hassine, "Synthesis and pharmacological profile of 6-methyl-3isopropyl-2H-1,2-benzothiazin-4(3H)-one 1,1-dioxide derivatives: non-steroidal anti-inflammatory agents with reduced ulcerogenic effects in the rat," European Journal of Pharmaceutical Sciences, vol. 16, no. 4-5, pp. 221-228, 2002.

[17] B. B. Aleksandrov, M. S. Gavrilov, V. D. Sviridov, N. D. Chkanikov, V. S. Shklyaev, and Y. V. Shklyaev, "Synthesis of the S-cis-oxime of 3,3-dimethyl-3,4-dihydroisoquinolyl-1carbaldehyde," Bulletin of the Academy of Sciences of the USSR, Division of Chemical Science, vol. 39, no. 9, pp. 1946-1947, 1990.

[18] M. Kammoun, R. Ben Salem, and M. Damak, "Acid-promoted oxygen-atom transfer from a novel dihydroisoquinolinederived oxaziridine substituted at position 1," Synthetic Communications, vol. 42, no. 15, pp. 2181-2190, 2012. 

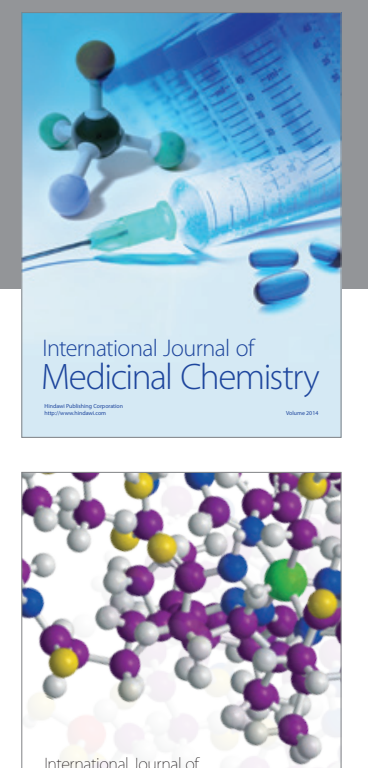

\section{Carbohydrate} Chemistry

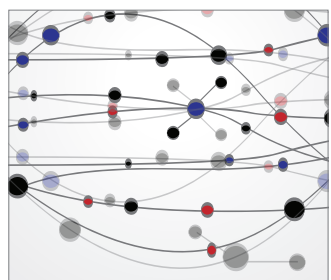

The Scientific World Journal
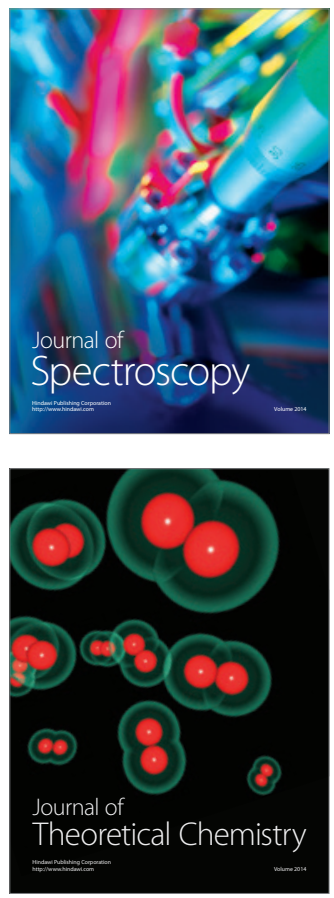
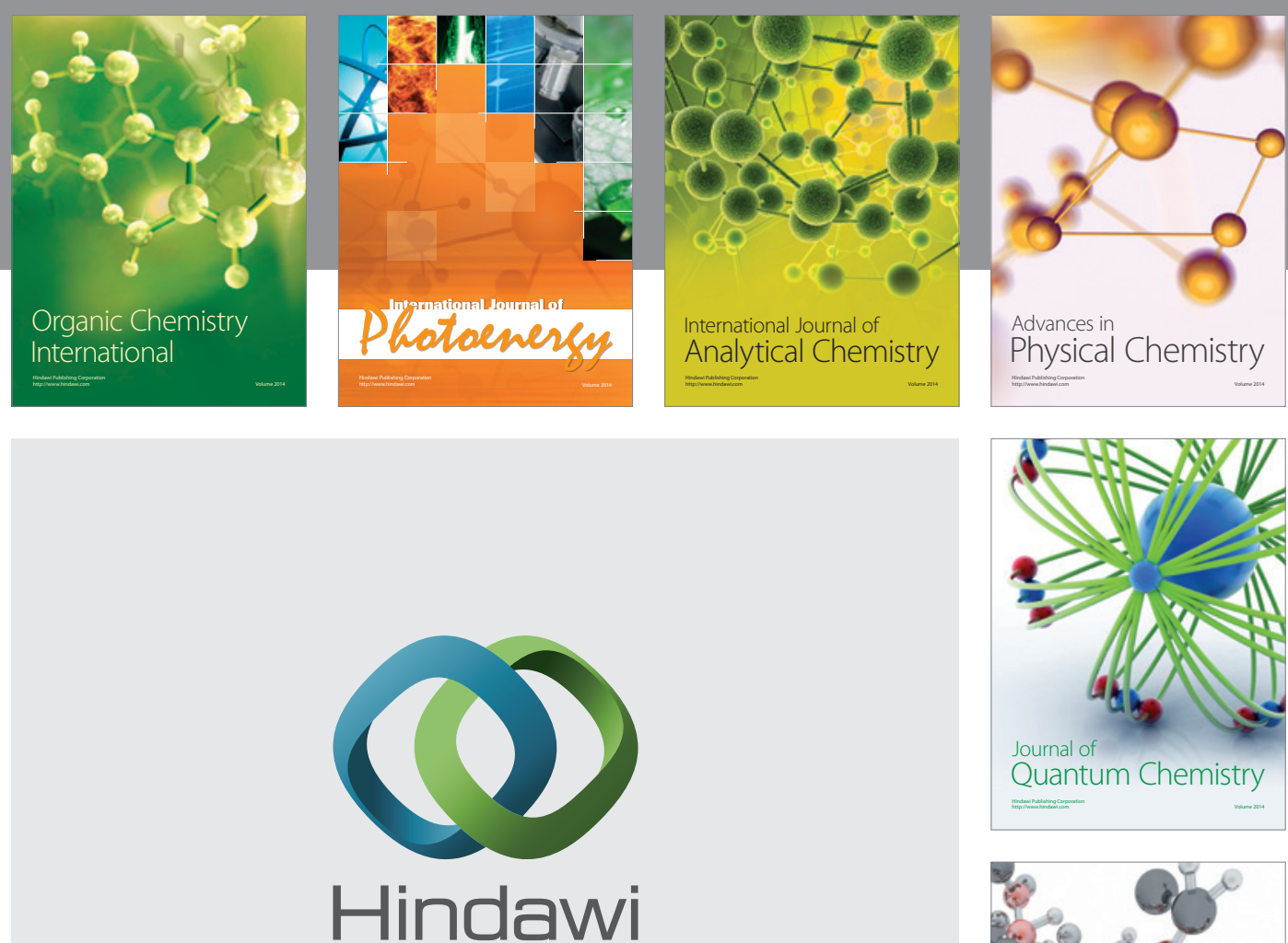

Submit your manuscripts at

http://www.hindawi.com

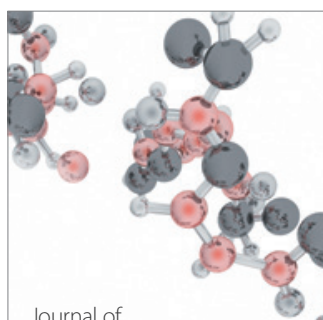

Analytical Methods

in Chemistry

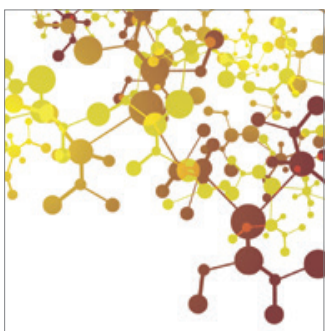

Journal of

Applied Chemistry

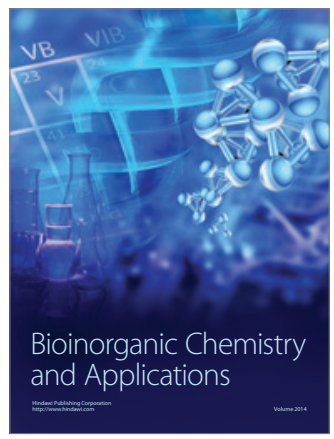

Inorganic Chemistry
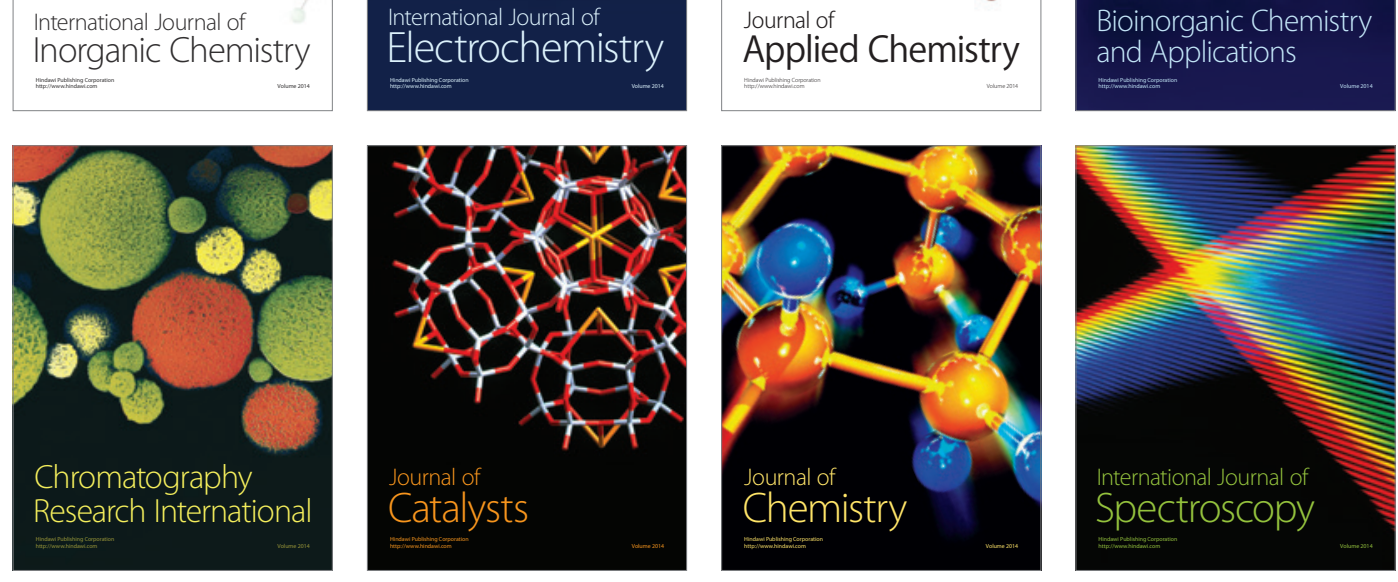